\title{
The Effect of Different Heat Treatment on the Nutritional Value of Milk and Milk Products and Shelf-Life of Milk Products. A Review
}

\author{
Assefa Bezie* \\ Milk and Milk Product Research Processing Industry Development Directorate, Ethiopian Meat and Dairy Industry Development Institute (EMDIDI), \\ Ethiopia
}

Submission: April 12, 2019; Published: May 15, 2019

*Corresponding author: Assefa Bezie, Milk and Milk Product Research Processing Industry Development Directorate, Ethiopian Meat and Dairy Industry Development Institute (EMDIDI), P.O.Box: 1573, Debre Zeit, Ethiopia

\begin{abstract}
This Review is concern on the effect of different heat treatment on the Nutritional Value of milk and milk Products and shelf-life of milk products. Milk and its derivatives are proposed as being useful foods throughout all life periods, in particular during childhood and adolescence, when their contents of calcium, protein, phosphorus, and other micronutrients might promote skeletal, muscular, and neurologic development. Temperature is the necessary environmental factor for the growth of microorganism. Heat treatment is the most widely used processing technology in the dairy industry. milk is treated at high temperature $\left(85^{\circ} \mathrm{C}\right.$ for $\left.2-3 \mathrm{~s}\right)$ in a short-time, flash process $\left(72-75^{\circ} \mathrm{C} / 15-30 \mathrm{~s}\right)$ in plate heaters; or by the low temperature or holder process, in which it is heated at 63-66 $\circ \mathrm{C}$ for at least 30-32 min, with stirring, and is then cooled. The fat, fat-soluble vitamins, carbohydrates and mineral' of milk are essentially unaffected by heal treatment. Proteins and water-soluble vitamins are the components which are mainly affected by the heat treatment. Pasteurization temperature, ranged from 72 to $94{ }^{\circ} \mathrm{C} / 15 \mathrm{~s} \mathrm{had} \mathrm{no} \mathrm{effect}$ on the microbiological and sensory shelf-life of aseptically packaged milk into plastic bottle, which lasted $11 \mathrm{~d}$ under storage at $9{ }^{\circ} \mathrm{C}$. During industrial yogurt manufacture, the mixes are generally heated at 90 or $95^{\circ} \mathrm{C}$ for $3-7 \mathrm{~min}$ before cooling down to fermentation temperature. It is well established that heat treatment implemented during yogurt manufacture affects the acidification rate and incubation time. The shelf life of "fresh" yogurt may be only a couple of weeks for unprotected operations and up to 6 weeks or more for well-operated, ultraclean operations. Cheese is the ripened or unripened soft, semi-hard, hard, or extra-hard product, which may be coated, and in which the whey protein/casein ratio does not exceed that of milk, obtained by coagulating wholly or partly the protein of milk, skimmed milk, partly skimmed milk, cream, whey cream or buttermilk, or any combination of these materials. The heating treatments and holding time significantly influenced yield, TS and protein recovery of cow milk Ricotta cheese. Heat treatment of milk $\left(72{ }^{\circ} \mathrm{C}\right.$, no hold) meant for Mozzarella cheese making improved protein and Total Solids (TS) recovery but decreased the fat recovery, gave soft-bodied cheese, improved flavor score and keeping quality and ensured public health safety. Generally, unprocessed milk held at high ambient temperatures has a shelf-life from 2-3 hours up to 24 hours. Cheese, however, has a shelf-life from 4-5 days up to five years depending on the variety. Churning at low temperature (TL) and TLW results in butter with an average water droplet size at day 5 of $5.5 \mathrm{~mm}$, while commercial butter had an average diameter of $2.8 \mathrm{~mm}$.
\end{abstract}

Keywords: Milk; Milk product; Heat treatment; Nutritional Value; Shelf-life

Abbrevations: SNV: Netherlands Development Organization; UHT: Ultra-High Temperature; HTST: High-Temperature Short-Time; IDF: International Dairy Federation; TS: Total Solids; SNF: Solids Nonfat; THW: Temperature High Water; TLW: Temperature Low Water

\section{Introduction}

Milk is produced from the mammary glands of mammals and it is a soul food for offspring of mammals. It contains in a balanced form all the necessary and digestible elements for building and maintaining the human and animal body. About $87 \%$ of milk composition consists of water and $13 \%$ are nutritionally important components, such as proteins, carbohydrates, lipids, minerals and vitamins. It is excellent source of high-quality protein, vitamins and minerals. It represents one of the best natural sources of essential amino acids for human nutrition. Moreover, milk is an outstanding source of calcium and phosphorus to build bones and teeth. Similarly, milk is the most nutritious and it can attribute for the growth, reproduction, energy source, maintenance and repairs of body. Also, due to having various properties, it can be easily converting into different milk products and to use it as an ingredient for other food items [1,2]. Milk contains components that are essential to humans such as proteins, carbohydrates, fat, water, all the B-vitamins, vitamins $\mathrm{A}$ and $\mathrm{D}$, calcium and phosphorus. It also provides energy $[3,4]$. 
Milk and its derivatives are proposed as being useful foods throughout all life periods, in particular during childhood and adolescence, when their contents of calcium, protein, phosphorus, and other micronutrients might promote skeletal, muscular, and neurologic development. In addition to milk, several dairy products such as cream, butter, yogurt, kefir, and cheese have been produced and consumed worldwide for millennia. Therefore, the impact of milk and dairy products on human health is quantitatively relevant and has been the subject of several investigations, on both whole products and their isolated components. In particular, the fat portion of milk (largely composed of SFAs) and some of its minor components, notably calcium and oligosaccharides, are being actively researched for their potential health roles [5]. The increasing awareness of what is "natural" or "unprocessed" often raises the question of how heat treatment affects the nutritional value of milk and other milk products [6]. The treatments can be categorized into those used for milk for direct consumption, such as pasteurization, Extended Shelf-Life (ESL) processing, UltraHigh Temperature (UHT) and in-container sterilization, and those used for specific dairy products such as yogurt and milk powders. In addition, termination used to treat raw milk, allows it to be stored for a longer time before further processing, or for cheese making [7].

Temperature is the necessary environmental factor for the growth of microorganism. Different microorganisms grow at different temperature $[8,9]$. The temperature normally starts to change as soon as the milk leaves the refrigerator cabinet and increases while the consumer completes the shopping and during the drive home, before being returned to a refrigerator bin the consumer's home [10]. The milk processing consists of following steps: agitation, mixing, and cooling at the farm; clarification, separation, and standardization; pasteurization; homogenization; packaging; all done by sanitation [11]. Milk that contains more fat in the solid state are more dispersed and viscous, thus, whole milk has a higher viscosity than skimmed milk. The viscosity of milk decreased after pasteurization process. The heat treatment during pasteurization had influence on the surface tension of fat globules in milk, which resulted in a slight increase of the surface tension of raw milk [12]. During milk processing, homogenization makes physicochemical changes that affect the characteristics of dairy products and develop their texture and flavor. The application of heat treatment in milk affects the flavor, the microbial content and the milk proteins. The more intense the heat treatment is, the more radical the changes that occur. Heat treatment also affects the texture of the produced yogurt, increasing the value of its texture characteristics (firmness, cohesiveness) and viscosity. Homogenization, typically used in dairy processing, is through application of pressure, reducing the milk fat globule size and preventing fat separation from the milk [13].

The dairy industry uses various means and technologies aimed at achieving an extension in product shelf-life. Some commonly used methods include heat treatment of fluid milk products for a pre-determined time and temperature; acidification by addition of starter culture in the case of cultured dairy products such as yogurt, kefir, or buttermilk; drying of milk concentrate to produce milk or skim milk powder; addition of pre-serving agents such emulsifying salts e.g., phosphates and citrates in shelf-stable processed cheeses. Shelf-life of fluid milk products, for instance, is dependent on various factors, namely heat treatment (also known as pasteurization), quality of the incoming raw milk, additional processes such as micro-filtration, filling conditions, temperature control and packaging technologies. However, heat treatment remains the primary factor that determines the span of the shelf-life [14]. Heat treatment is the most widely used processing technology in the dairy industry. Its main purpose is to destroy microorganisms, both pathogenic and spoilage, to ensure the milk is safe and has a reasonable shelf-life. Despite the developments of alternative technologies such as high-pressure processing and pulsed electric field technology for destroying microorganisms, thermal treatment remains the method of choice for most bactericidal treatments in the dairy industry, and in the processing of other foods [7]. Therefore, this review study is initiated to identify the effect of heat treatment on the Nutritional Value of Dairy and Dairy Products, to determine the shelf-life and the time duration of milk and milk products.

\section{Dairy Products and Heat Treatment \\ Pasteurized and UHT Milk}

The Dairy industry has been commonly applying a pasteurization process known as HTST (High-Temper-atureShort-Time) which uses a combination of time-temperature of 72 ${ }^{\circ} \mathrm{C}$ for at least 15 seconds [14]. This result agrees with the finding of Grosch [2] milk is treated at high temperature ( $85{ }^{\circ} \mathrm{C}$ for 2 -s) in a short-time, flash process $\left(72-75^{\circ} \mathrm{C} / 15-30 \mathrm{~s}\right)$ in plate heaters; or by the low temperature or holder process, in which it is heated at $63-66{ }^{\circ} \mathrm{C}$ for at least $30-32 \mathrm{~min}$, with stirring, and is then cooled. Pasteurization and then the commercial sterilization increased the $\mathrm{pH}$ of milk, with consequent decrease in acidity. This increased $\mathrm{pH}$ can be explained by lower whey protein associating with the micelles. Pasteurization and ultra-high temperature processes altered the composition of the milk slightly, decreasing total fat and total solids and increasing urea [15].

The fat, fat-soluble vitamins, carbohydrates and mineral' of milk are essentially unaffected by heal treatment. Proteins and water-soluble vitamins are the components which are mainly affected by the heat treatment [16]. This contrasts the report of Jose [15] Pasteurized and ultra-high temperature milks kept protein and lactose content similar to raw milk. Lactose seems to be little affected by traditional heat processing procedures or during drying. Pasteurization alone appears to cause no change in the vitamin A and carotene content of milk, but when this process is followed by evaporation as in the manufacture of condensed milk, there are loses of $20 \%$ of the vitamin A, although carotene is not affected. Vitamin E content of milk is not influenced by pasteurization or evaporation but a loss of $9 \%$ may occur after drying and reconstitution. Vitamin D also appears to suffer no 
loss during heat processing of milk. There is no loss of vitamins of the B-complex group riboflavin, nicotinic acid, pyridoxine, pantothenic acid and biotin by heat treatment. But the losses of BI (thiamin), B12 and C increase from 10-20\% in pasteurization and UHT treatment, to $90 \%$ loss of B12 in bottle sterilization and evaporation [16].

Pasteurization temperature, ranged from 72 to $94{ }^{\circ} \mathrm{C} / 15 \mathrm{~s} \mathrm{had}$ no effect on the microbiological and sensory shelf-life of aseptically packaged milk into plastic bottle, which lasted $11 \mathrm{~d}$ under storage at $9{ }^{\circ} \mathrm{C}$ [17]. According to IDF [14], under the most favorable processing and storage conditions, this HTST pasteurization process is capable of extending the shelf-life of milk for up to 3 weeks de-pending on the initial microbiological quality of the raw milk. UHT process is a recent introduction for the production of sterilized milk [16], which uses a high temperature $\left(>135^{\circ} \mathrm{C}\right)$ for 1-2 seconds [14]. Heat treatments, such as pasteurization and UHT processes, have little effect on the net protein utilization (NPU) of milk proteins, although the classic in bottle (Table 1).

Table 1: Comparison of different heat treatment to milk.

\begin{tabular}{|c|c|c|c|}
\hline \multirow{2}{*}{ Parameters Reference enzyme } & HTST pasteurization & ESL & UHT \\
\cline { 2 - 4 } & Phosphatase $(-)$ & Phosphatase $(-)$ & Phosphatase $(-)$ \\
\hline Storage conditions & Refrigerated & Refrigerated & Aseptic \\
\hline Packaging & Clean & Aseptic & $>6$ months \\
\hline Shelf-life & $10-14 \mathrm{~d}$ & $30-60 \mathrm{~d}$ & \\
\hline
\end{tabular}

Sterilization procedure and the in bottle resterilization of UHT milk cause losses in true digestibility and a fall in biological value (BV) due to reduced availability of lysine and methionine [16]. UHT products are practically sterile and can be stored at ambient temperature for a long time (e.g. "long-life milk"). The dairy industry has adopted newer processing technologies that can increase the shelf life of fluid milk beyond its traditional life with minimal adverse effects on its quality and taste (generally referred to as Extended Shelf-life (ESL) milk). Examples include Higher-Heat-shorter-time (HHST) is one means of extending the shelf-life of milk to over 50 days at refrigerated storage conditions [14].

\section{Yoghurt and its Shelf-Life}

Source: Corrieu et al., [18]

Figure 1: Schematic diagram of the production processes of set-type, stirred, drinking, and concentrated yogurts.

In essence, yogurts are fermented dairy products obtained from lactic acid fermentation by two species of lactic acid bacteria, that is, Streptococcus thermophilus and Lactobacillus delbrueckii subsp. Bulgaricus [18].Yogurt is a highly nutritious and easily digestible dairy product which is a rich source of more than ten essential nutrients in particular, certain minerals and vitamins [19]. There are many different types of yogurt [20]. The common types of yogurt are set, stirred, and drinking yogurt, and they are found in most developed markets around the world [21]. The traditional product is set yogurt, made of concentrated milk. Set yogurt is fermented after being packaged, implying that final cooling has to be achieved in the package. Another type is stirred yogurt, almost always made from nonconcentrated milk. After a gel is formed, it is gently stirred to obtain a smooth and fairly thick, 
but still pourable, product. Stirred yogurt is almost fully fermented before it is packaged. From milk fermented with yogurt bacteria, several products can be derived, such as yogurt drinks, yogurt ice cream, and fruit yogurt. The starting milk for the manufacture of most yogurt drinks is standardized skimmed milk, which is pasteurized for $15 \mathrm{~min}$ at $85{ }^{\circ} \mathrm{C}$ to $95^{\circ} \mathrm{C}$. The milk is fermented with the yogurt bacteria at $43^{\circ} \mathrm{C}$ till a pH of around 4.0 is reached [22].This study agrees with the finding of Corrieu [18] who reported that during industrial yogurt manufacture, the mixes are generally heated at 90 or $95^{\circ} \mathrm{C}$ for 3-7 min before cooling down to fermentation temperature. Plate heat exchangers, with a tubular in order to cool the mix accurately at the fermentation holding zone, are generally used and are designed temperature (between 37 and $43^{\circ} \mathrm{C}$ ) (Figure 1).

The best incubation temperature is $45^{\circ} \mathrm{C}$ which gave the best quality with regard to (total acidity (T.A), whey volume, viscosity and the average value of sensory quality) in comparison with incubation temperatures $41^{\circ} \mathrm{C}$ and $43{ }^{\circ} \mathrm{C}$ (large amount of whey separated and decrease in consistency). The storage temperature of $6{ }^{\circ} \mathrm{C}$ gave the best quality with regard to (total acidity, whey volume, viscosity and total score for sensory quality) compared to storage temperature of $10^{\circ} \mathrm{C}$ which gave large amount of separated whey and bitterness. The viscosity of yoghurt held at temperature of $6{ }^{\circ} \mathrm{C}$ gave better results than that held at temperature of 10 ${ }^{\circ} \mathrm{C}$, however, low temperature increased viscosity and improved product firmness and stability. The acidity of yoghurt held at temperature of $6^{\circ} \mathrm{C}$ was better than that held at temperature of 10 ${ }^{\circ} \mathrm{C}$. Higher temperature (temperature of $10^{\circ} \mathrm{C}$ ) can lead to defects such as bitterness and low temperature (temperature of $6{ }^{\circ} \mathrm{C}$ ), can reduce the fermentation and allow the desired acidity to be reached [23].
It is well established that heat treatment implemented during yogurt manufacture affects the acidification rate and incubation time. Thus, the reduction of incubation time is due to whey protein denaturation. The greater the whey protein denaturation induced, the shorter the incubation period achieved. The milk fat content of yogurt significantly influenced the incubation time, viscosity, acetaldehyde, and acidity. Yogurts prepared using skim milk had lower incubation rates but had greater viscosity, acetaldehyde, and lactic acid concentrations. The fortification of milk solids commonly increases the incubation time of yogurt [24]. It is worth stating again that the standard and hygiene of processing and filling operations is what normally determines the shelf life of yogurt products. The shelf life of "fresh" yogurt may be only a couple of weeks for unprotected operations and up to 6 weeks or more for well-operated, ultraclean operations [21]. Of these materials, through the action of rennet or other suitable coagulating agents [25]. Cheese is made in almost every country of the world and there exist more than 2000 varieties [26].

\section{Cheese}

Cheese is the ripened or unripened soft, semi-hard, hard, or extra-hard product, which may be coated, and in which the whey protein/casein ratio does not exceed that of milk, obtained by coagulating wholly or partly the protein of milk, skimmed milk, partly skimmed milk, cream, whey cream or buttermilk, or any combination.

\section{Soft Cheese}

Soft cheeses fall into two categories; ripened soft cheese such as brie and fresh cheese and unripened cheese such as cottage cheese. Soft cheeses are made from heat treated milk which is fermented by the use of specific bacteria. Artificial rennet is sometimes used to produce a firmer texture [27] (Figure 2).

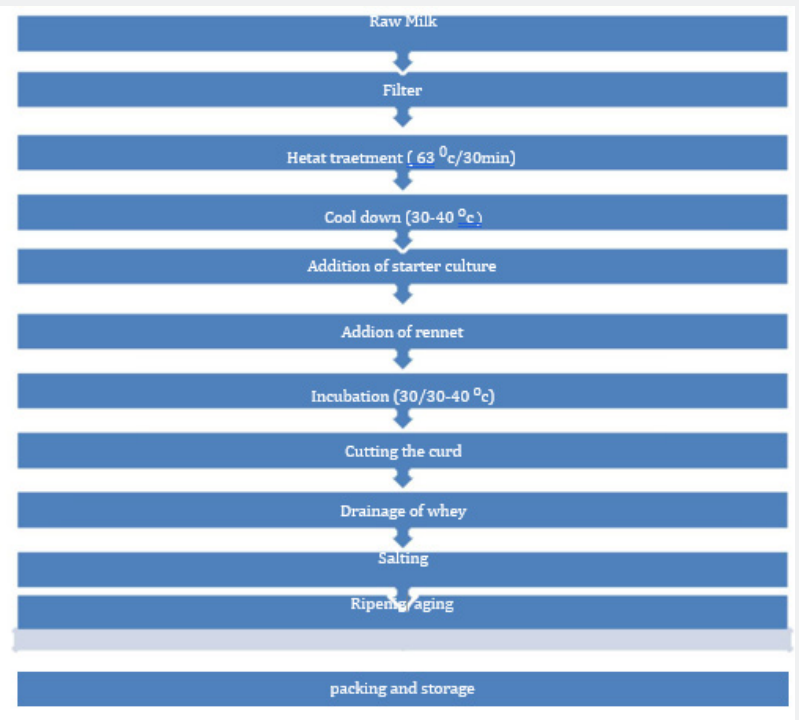

Source: The Authors compiled from different sources

Figure 2: Flow diagram of the production of soft cheese. 
Ricotta is a soft, spreadable and unripened variety of whey cheese. The heating treatments and holding time significantly influenced yield, TS and protein recovery of cow milk Ricotta cheese [28]. As reported by Mohamed [29] the fat content was not significantly affected by heat treatment. However, the highest fat content was in cheese from heat treated milk at $63{ }^{\circ} \mathrm{C} / 30 \mathrm{~min}$ $(21.95 \pm 3.37 \%)$. The raw milk cheese showed the highest protein content $(23.85 \pm 1.60 \%)$, while cheese from heat treated milk at $63{ }^{\circ} \mathrm{C} / 30 \mathrm{~min}$ had the lowest protein content $(20.80 \pm 1.85 \%)$. The low protein content of heat-treated milk cheese could be explained by the protein degradation as the result of increased moisture due to the heat treatment. The total solids content decreased as the temperature of heat treatment increased. The ash content of raw milk cheese scored the highest $(3.70 \pm 0.55 \%)$, while cheese from heat treated at $63{ }^{\circ} \mathrm{C} / 30 \mathrm{~min}$ had the lowest ash content $(2.29 \pm 1.22 \%)$. The titratable acidity of cheese was significantly highest in cheese made from raw milk $(0.55 \pm 0.09 \%)$ and lowest when cheese was made from heat-treated milk at 63 ${ }^{\circ} \mathrm{C} / 30(0.24 \pm 0.03 \%)$. The highest acidity of raw milk cheese could be due to the fact that storage temperature activated the natural micro flora of raw milk to develop acidity as the result of lactose fermentation since the cheese was stored at room temperature.

Fresh cheeses are ready for use as soon as the manufacturing process is complete but ripened cheeses are allowed to mature in temperature and humidity-controlled rooms for up to one month [27]. According to Bastin [30], Soft Cheeses such as Brie, Camembert, Limburger, Blue, Cottage, Cream, and Neufchâtel are more perishable because of their higher water content. They should be stored in a tightly sealed container and used within two weeks.

\section{Semi-Hard Cheese}

Semi-firm cheeses are those which hold their shape for slicing, and which can be shredded, but which aren't soft enough to spread, and not hard enough to grate. They tend to have a moisture level between 40 and $60 \%$ and can be ripened or unripened [31]. NDC [32] reported that example of semi-soft cheese includes Blue, brick, feta, Havarti, Monterey Jack, mozzarella, Meunster, provolone. Heat treatment of milk $\left(72{ }^{\circ} \mathrm{C}\right.$, no hold) meant for Mozzarella cheese making improved protein and Total Solids (TS) recovery but decreased the fat recovery, gave soft-bodied cheese, improved flavor score and keeping quality and ensured public health safety [33]. The Mozzarella cheese when packaged in cryovac package in PVDC film and stored under refrigeration $\left(5^{\circ} \mathrm{C}\right)$ and deep freeze kept well for 42 and 90 days, respectively [34].

\section{Hard Cheese}

Hard cheeses such as Cheddar and Cheshire retain most of the protein, fat, calcium, and some other minerals, and vitamins such as vitamin A, riboflavin (vitamin B2), and vitamin. Hard cheeses include Cheddar, Cheshire, Derby, Gloucester, and Leicester (British), Cantal (French), Friesian and Leiden (Netherlands), Graviera and Kefalotiri (Greece), Manchego, Idiazabal, Roncal, and Serena (Spain), Sâo Jorge (Azores, Portugal), and Ras (Egypt).Hard cheeses have a moisture content of $35-40 \%$ and are manufactured by a generally similar technology, including renneting at $\sim 30$ ${ }^{\circ} \mathrm{C}$, cutting the coagulum into small pieces, cooking to $\sim 40{ }^{\circ} \mathrm{C}$, drainage of the whey and pressing the curd [35]. This result agrees with the finding of NDC [32] who obtained Cheddar, Colby, Edam, Gouda, Swis are some of hard cheeses which produced at dairy processing plants.

Heat treatment of milk at $64-68{ }^{\circ} \mathrm{C} / 10$ s indirectly influences cheese yield by pre-venting losses of milk solids during storage. Thermization leads to an immediate reduction in the numbers of protolithic bacteria and the storage life of the milk is not as dependent on the microbiological quality of the raw milk as it is with low temperature storage. Cheddar cheese was made from pasteurized $\left(63{ }^{\circ} \mathrm{C}\right.$ for $30 \mathrm{~min}$ ) and raw milk to determine the influence of pasteurization on cheese yield and on fat and nitrogen (i.e., protein) recovery in cheese. Pasteurization had no effect on fat recovery in cheese, but nitrogen recovery was higher for cheese made from pasteurized milk. Composition-adjusted cheese yield was higher in cheese made from pasteurized milk [36,37].

Source: Vrdoljak et al., [37]

Figure 3: The shelf-life of cheese based on microbiological parameters. 
The two different heat treatments induced various denaturation and therefore different aggregation ratios. When the primary emulsion was treated by a low heat treatment $(72$ $\left.{ }^{\circ} \mathrm{C} / 20 \mathrm{~s}\right)$, only $5 \%$ of the whey proteins were aggregated $( \pm 1 \%)$ while the high heat treatment $\left(94^{\circ} \mathrm{C} / 40 \mathrm{~s}\right)$ led to an aggregation of around $55 \%( \pm 4 \%)$ of the whey proteins [38]. Addition of preservative can prolong shelf life of cheeses but in selection of proper additive, sensory properties of special cheese and dosage of additives must be considered [39]. Generally, unprocessed milk held at high ambient temperatures has a shelf-life from 2-3 hours up to 24 hours. Cheese, however, has a shelf-life from 4-5 days up to five years depending on the variety [26] (Figure 3).

\section{Butter}

Traditionally, butter is defined as a plastic product derived from cream, inverted to a water-in-oil emulsion (W/O) with minimum $80 \%$ fat. In the dairy industry today the majority of the butter is produced on continuous butter making machines using the so-called Fritz method. Initially, the milk is concentrated to cream followed by a pasteurization process. Subsequently, the cream follows a temperature treatment where crystallization takes place. The churning process involves phase inversion of the crystallized cream to butter granules and buttermilk [40] (Figure 4). To produce butter, you have to make the butter fat more concentrated. Butter should contain $80 \%$ fat, $16 \%$ moisture, and $2 \%$ milk solids nonfat (SNF). It may contain a small amount of salt $(2 \%)$ to improve shelf life and taste. However, excess moisture (more than 20\%) reduces the quality of butter [20]. Cream was matured for $1.5 \mathrm{~h}$ at either $100 \mathrm{C}$ or $22^{\circ} \mathrm{C}$ and subsequently churned at the maturing temperature. Moreover, the churning time is shown to depend on churning temperature, as a churning temperature at $10{ }^{\circ} \mathrm{C}$ results in a churning time of 89 $\mathrm{s}$ and a temperature increase during churning of $1.2^{\circ} \mathrm{C}$, whereas churning temperature at $22^{\circ} \mathrm{C}$ gives a churning time of $57 \mathrm{~s}$ and a temperature increase of $0.2^{\circ} \mathrm{C}[41]$.

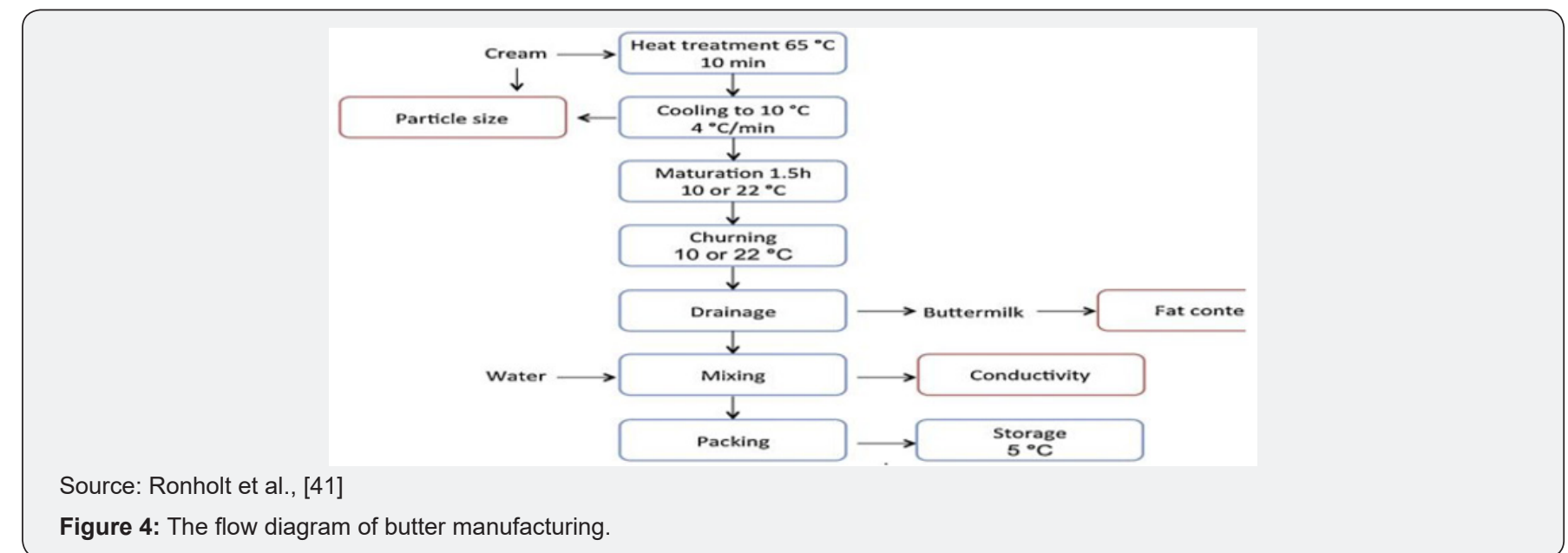

Rønholt [42] have been reported traditionally, the churning temperature is in the range from 10 to $15{ }^{\circ} \mathrm{C}$. Such increase in churning temperature led to a decreased churning time and consequently a lower degree of shear during churning compared to a churning temperature of $10{ }^{\circ} \mathrm{C}$.However, a low churning temperature allows more water to be incorporated into the system and a higher SFC (solid not fat), without affecting the rheological properties of the product when comparing to a high churning temperature. One could speculate that an intermediate churning temperature could be of industrial interest, if b-crystals could be avoided and on the same time much water incorporated into the system [41]. As report shown [42] Churning at temperatures below $5{ }^{\circ} \mathrm{C}$ results in such a high SFC that only a small amount of liquid fat can be squeezed out of the fat globules during churning. The high-water content in THW (temperature high water) and TLW (temperature low water) reveals no significant effect on the polymorphic behavior in the butter Increasing the water content in the butter from $22 \%$ to $28 \%$ (weight/weight) does not affect the solid fat content after water correction. However, butter churned at $10{ }^{\circ} \mathrm{C}$ contains more solid fat facilitating incorporation of more water in the butter .matrix, when compared to butter churned at $22{ }^{\circ} \mathrm{C}$. Churning at low temperature (TL) and TLW results in butter with an average water droplet size at day 5 of $5.5 \mathrm{~mm}$, while commercial butter had an average diameter of $2.8 \mathrm{~mm}$ [43]. An increase in the churning temperature from 10 to $22^{\circ} \mathrm{C}$ leads to a significant increase in water droplet size, with an average value of $18.5 \mathrm{~mm}$, corresponding to a decreased SFC. It is well documented, that both thermal treatment and shear affects the crystallization behavior of milk fat-based products [41] (Table 2).

Table 2: Estimated shelf-life of butter at $10^{\circ} \mathrm{C}, 15^{\circ} \mathrm{C}, 25^{\circ} \mathrm{C}$, and $35^{\circ} \mathrm{C}$.

\begin{tabular}{|c|c|}
\hline Temperature $\left({ }^{\circ} \mathrm{C}\right)$ & Butter Shelf life (months) \\
\hline 10 & 21.94 \\
\hline 15 & 17.18 \\
\hline 25 & 6.10 \\
\hline 35 & 0.58 \\
\hline
\end{tabular}

Source: Jung et al. [43]

\section{Conclusion and Recommendation}

Milk contains components that are essential to humans such as proteins, carbohydrates, fat, water, all the B-vitamins, vitamins A 
and D, calcium and phosphorus. It also provides energy. The dairy industry uses various means and technologies aimed at achieving an extension in product shelf-life. Some commonly used methods include heat treatment of fluid milk products for a predetermined time and temperature; acidification by addition of starter culture in the case of cultured dairy products such as yogurt, kefir, or buttermilk; drying of milk concentrate to produce milk or skim milk powder; addition of preserving agents such emulsifying salts. However, heat treatment remains the primary factor that determines the span of the shelf-life. Pasteurization and ultrahigh temperature processes altered the composition of the milk slightly, decreasing total fat and total solids and increasing urea. Generally, unprocessed milk held at high ambient temperatures has a shelf-life from 2-3 hours up to 24 hours. Cheese, however, has a shelf-life from 4-5 days up to five years depending on the variety.

\section{Recommendation}

a. Further investigations on the shelf-life of each milk products are necessary.

b. Should be Encourage actors in the dairy value chain and the dairy industries to prevent selling of raw milk.

c. The effect of heat treatments on the nutritional value of Ice cream, buttermilk and rest of dairy and dairy products with microbiological aspect should be done.

d. Storing milk and milk products at proper temperature and place to extend the shelf-life.

e. Further investigations on the physio-chemical compositions of sheep milk and its shelf-life.

\section{References}

1. SNV (2017) Hygienic and Quality Milk Production Training Package for Dairy Extension workers.

2. Grosch Werner (2008) milk and dairy products, Germany Research Center for Food and Chemistry.

3. Ebing P, Rutgers K (2006) Preparation of dairy products. Agromisa Foundation and CTA, Wageningen.

4. Millogo V, Sissao M, Sidibé GA, Ouédraogo AG (2014) Effect of storage time and temperature on raw milk composition of dairy cattle in tropical conditions. Afr J Dairy Farming Milk Prod 2(1): 104-108.

5. Visioli F, Strata A (2014) Milk, Dairy Products, and Their Functional Effects in Humans: A Narrative Review of Recent Evidence. American Society for Nutrition. Adv Nutr 5: 131-143.

6. CEPMSA (Consumer Education Project of milk SA) (2016) The effect of heat treatment on the nutritional value of milk and milk products.

7. SNV (2018) Heat Treatment of Milk - Overview.

8. Patil SS, Zagare MS, Ghorade IB, Deshmukh AM (2014) Isolation of Pathogens from Dairy Products and Effect of Temperature on Pathogens. Indian Journal of Research 3(1): 2250.

9. Yano M, Shimadzu H, Endo T (2014) Modelling temperature effects on milk Production: a study on Holstein cows at a Japanese farm. Springer Plus 3:129.

10. Paul Sadhu S (2017) Effect of cold chain interruptions on the shelflife of fluid pasteurized skim milk at the consumer stage. Braz J Food Technol 21: e2017064.
11. Massoud R, Belgheisi S, Massoud A (2016) Effect of High-Pressure Homogenization on Improving the Quality of Milk and Sensory Properties of Yogurt: A Review. International Journal of Chemical Engineering and Applications 7:1.

12. Šestan I, Odobašić A, Bratovčić A (2016) The effect of heat treatment on the physical-chemical properties of milk. Acad J Environ Sci 4(7): 131-136.

13. Sfakianakis P, Tzia C (2014) Conventional and innovative processing of milk for yogurt manufacture, development of texture and flavor: A review. Foods 3: 176-193.

14. IDF (2012) Shelf-life of Dairy Products.

15. Jose MP, Adriano G, Bruna WM, Daniel NL, Claucia FV de Souza (2015) Effects of Pasteurization and Ultra-High Temperature Processes on Proximate Composition and Fatty Acid Profile in Bovine Milk. American Journal of Food Technology 10(6): 265-272.

16. Sharma RK (1980) Effect of Heat Treatment on the Nutritive Value of Milk. Indian Dairyman 32(8): 619-621.

17. Petrus RR, Freire MTA, Setogute LC, Higajo VM (2011) Effect of pasteurization temperature on aseptically fi lled milk shelf life. Alim Nutr Araraquara 22(4): 531-538.

18. Corrieu G, Béal C (2016) Yogurt: The Product and its Manufacture. In: Caballero B, Finglas P, Toldrá F (Eds.), the Encyclopedia of Food and Health, Oxford, UK, 5: 617-624.

19. Weerathilake VDAW, Rasika DMD, Ruwanmali UKJ, Munasinghe DDMA (2014) The evolution, processing, varieties and health benefits of yogurt. International Journal of Scientific and Research Publications 4(4): 2250-3153.

20. Tessema A, Tibbo M (2009) Milk Processing Technologies for SmallScale Producers, Technical Bulletin.

21. Mac Bean D, Roger (2010) Packaging and the Shelf Life of Yogurt, South Brisbane, Australia.

22. Walstra P, Wouters J, Geurts T (2006) Dairy Science and Technology Second Edition.

23. Hassan A, Mudawi Abdelrahim SMK, Abdallah MI Mustafa (2014) Effect of incubation and storage temperatures on Quality of set Yoghurt. Egypt. Acad J Biolog Sci 6(2): 131-137.

24. Soukoulis C, Panagiotidis P, Koureli R, Tzia C (2007) Industrial Yogurt Manufacture: Monitoring of Fermentation Process and Improvement of Final Product Quality. American Dairy Science Association, J Dairy Sci 90: 2641-2654.

25. Codex Standard (1978) condex Generla Standard for cheese.

26. O'Connor CB (1993) Traditional cheesemaking manual. ILCA (International Livestock Centre for Africa), Addis Ababa, Ethiopia.

27. Enwa F, Avbunudiogba A, John C, Godstime, Omojate (2013) Physiochemical Comparism of Three Different Types of Soft Cheese. Journal of Environmental Science, Toxicology and Food Technology 4(5): 11-17.

28. Shelke A, Sabikhi L, Khetra Y, Ganguly S (2018) Effect of Heat Treatment on Quality Parameters of Cow Milk Ricotta Cheese. Dairy Technology Division, ICAR-National Dairy Research Institute, Karnal.

29. Mohamed OMA, Omer IA (2010) Effect of Heat Treatment, Level of Sodium Chloride, Calcium Chloride on the Chemical Composition of White Cheese. Research Journal of Animal and Veterinary Sciences 5: 69-72.

30. Bastin Sandra (2004) Cheese Basics.UK Cooperative Extension Service. 31. https://www.cooksinfo.com/semi-firm-cheeses.

32. NDC (National Dairy Council) (2000) Cheese. 
33. Patel GC, Vyas SH, Upadhyay KG (1986) Evaluation of mozzarella cheese made from buffalo milk using direct acidification technique. Int J Dairy Sci 39: 394-403.

34. Ghosh BC, Singh S (1992) Storage studies of mozzarella cheese. 1: Sensory and rheological characteristics. Indian J Dairy Sci 45: 199-202.

35. Buttriss J (2003) Encyclopedia of Food Sciences and Nutrition (second Edition).

36. Ahmed NS, Abd El-Gawad MAM (2011) Cheese yelled as affected by some parameters: review. Acta Sci Pol Technol Aliment 10(2): 131-153.

37. Vrdoljak J, Dobranić V, Filipović I, Zdolec N (2016) Microbiolgical Quality of soft, semi-hard and hard cheeses during the shelf-life. Mac Vet Rev 39(1): 59-64.

38. Coutouly A, Riaublanc A, Axelos M, Gaucher I (2013) Effect of heat treatment, final $\mathrm{pH}$ of acidification, and homogenization pressure on the texture properties of cream cheese.
39. Jalilzadeh A, Tunçtürk Y,Hesari J (2015) Extension Shelf Life of Cheese: A Review. International Journal of Dairy Science 10(2): 44-60.

40. SPX (2012) Butter Production - Technology and Process.

41. Rønholt S (2014) Effect of churning temperature on water content, rheology, microstructure and stability of butter during four weeks of storage. Food Structure.

42. Rønholt S, Mortensen K, KnudsenJ (2013) The Effective Factors on the Structure of Butter and Other Milk Fat-Based Products. Comprehensive Reviews in Food Science and Food Safety, Institute of Food Technologists.

43. Jung-Min Park, Jin-Ho Shin, Da-Jeong Bak, Na-kyeong Kim, Kwang-Sei Lim, et al. (2014) Determination of Shelf Life for Butter and Cheese Products in Actual and Accelerated Conditions. Korean J Food Sci An 34(2): 245-251.

\section{Your next submission with Juniper Publishers}

\section{will reach you the below assets}

- Quality Editorial service

- Swift Peer Review

- Reprints availability

- E-prints Service

- Manuscript Podcast for convenient understanding

- Global attainment for your research

- Manuscript accessibility in different formats

( Pdf, E-pub, Full Text, Audio)

- Unceasing customer service

Track the below URL for one-step submission https://juniperpublishers.com/online-submission.php 